\title{
Photocatalytic Degradation of Camphor by Suspended and Immobilized Photocatalysts
}

\author{
Carla Sirtori, ${ }^{a}$ Adriane M. de Freitas, ${ }^{a}$ Sérgio Toshio Fujiwara ${ }^{b}$ and \\ Patricio Peralta-Zamora*,a
}

\author{
${ }^{a}$ Departamento de Química, Universidade Federal do Paraná, CP 19081, 81531-990 Curitiba-PR, Brazil \\ ${ }^{b}$ Departamento de Química, Universidade Estadual do Centro-Oeste, \\ Rua Simeão Camargo Varela de Sá, 03, 85040-080 Guarapuava-PR, Brazil
}

\begin{abstract}
Neste trabalho, a degradação de cânfora em solução aquosa foi avaliada utilizando-se processos fotocatalíticos mediados por suspensões e formas imobilizadas de $\mathrm{TiO}_{2}$ e $\mathrm{ZnO}$. Os catalisadores suportados $\left(\mathrm{TiO}_{2}\right.$ /anéis de vidro, $\mathrm{TiO}_{2}$ /alginato de cálcio e $\mathrm{ZnO} /$ alginato de cálcio) foram caracterizados por microscopia eletrônica de varredura com espectroscopia de energia dispesiva de raios $X$ (SEM/EDX), difratometria de raios $X(X R D)$, fluorescência de raios $X$ por energia dispersiva (EDXRF) e espectroscopia Raman, técnicas que permitiram confirmar a elevada porosidade dos materiais, assim como as fases cristalinas características (anatase e wurtzita). A eficiência de degradação dos fotocatalisadores suportados foi comparada com a dos semicondutores em suspensão, observando-se resultados comparáveis entre $\mathrm{TiO}_{2}$ Degussa P25 e $\mathrm{TiO}_{2}$ imobilizado em anéis de vidro. Por outro lado, o uso de esferas de alginato de cálcio propiciou menores eficiências de degradação, provavelmente em decorrência da significativa redução da área superficial nos sistemas imobilizados.
\end{abstract}

In this work, the degradation of aqueous solution of camphor by heterogeneous photocatalysis was study using suspended and supported $\mathrm{TiO}_{2}$ and $\mathrm{ZnO}$. The supported catalysts $\left(\mathrm{TiO}_{2} /\right.$ borosilicate reaching ring, $\mathrm{TiO}_{2}$ /calcium alginate and $\mathrm{ZnO}$ /calcium alginate) were characterized by scanning electron microscopy coupled with energy dispersive X-ray spectroscopy (SEM/EDX), X-ray diffractometry (XRD), energy dispersive X-ray fluorescence (EDXRF) and Raman spectroscopy, techniques that permitted to confirm the porosity of the material as well as the characteristic crystalline forms (anatase and wurtzite). The degradation efficiency of the supported photocatalysts was compared with the performance of free $\mathrm{TiO}_{2}$ and $\mathrm{ZnO}$, observing comparable results between conventional Degussa $\mathrm{P} 25 \mathrm{TiO}_{2}$ and $\mathrm{TiO}_{2}$ immobilized in glass-rings. On the other hand, the use of calcium alginate beads leads to lower degradation efficiency probably due to the significant area reduction observed in immobilized systems.

Keywords: camphor, photocatalysis, immobilized photocatalysts, $\mathrm{TiO}_{2}, \mathrm{ZnO}$

\section{Introduction}

In the last decades, many works have demonstrated the high degradation capacity of heterogeneous photocatalysis, mainly with the use of titanium dioxide $\left(\mathrm{TiO}_{2}\right)$ as photocatalyst. ${ }^{1}$ Interesting and complete revisions were recently published, remarking some important environmental applications. ${ }^{2,3}$ Many recalcitrant pollutants can be quickly degraded and mineralized by heterogeneous photocatalysis, usually with low influence of its chemical

*e-mail: zamora@ufpr.br nature. ${ }^{3}$ In view of this fact, photocatalysis has been successfully used for degradation of pesticides, ${ }^{4}$ polycyclic aromatic hydrocarbons, ${ }^{5}$ textile dyes, ${ }^{6}$ spill oils, ${ }^{7}$ among other substrates of environmental relevance.

Even involving complex reductive and oxidative mechanisms, favored by the high oxidant character of the positive hole $\left(\mathrm{E}^{0}=+2.53 \mathrm{~V} v\right.$ s. $\left.\mathrm{ENH}\right)$ and the moderate reductive capacity of the electron $\left(\mathrm{E}^{0}=-0.52 \mathrm{~V} v s\right.$. $\left.\mathrm{ENH}\right)$, it is admitted that the main reaction mechanism is mediated by hydroxyl radical. This is a strong oxidant agent $\left(\mathrm{E}^{0}=+2.80 \mathrm{~V} v\right.$ s. $\left.\mathrm{ENH}\right)$ that results from the reaction between the positive hole and hydroxyl ion (or water molecules) 
previously adsorbed onto the photocatalyst surface (equations 1-2). Usually, heterogeneous photocatalytic reactions mediated by hydroxyl radicals show velocity between $10^{6}$ and $10^{9} \mathrm{~mol} \mathrm{~L}^{-1} \mathrm{~s}^{-1} .{ }^{3}$ These mainly involve hydrogen abstraction in saturated organic compounds (equation 3), electron transference in neutral or charged inorganic compounds (equation 4) and radical addition in aromatic molecules (equation 5).

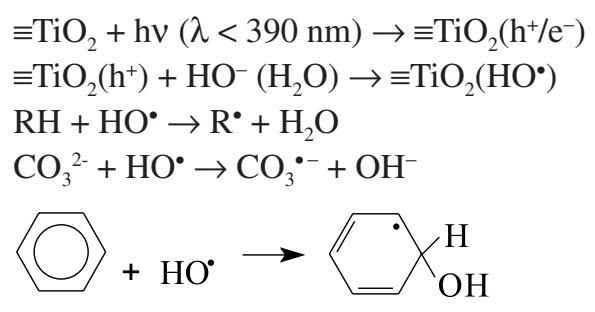

Even showing high degradation efficiency, the implementation of large-scale heterogeneous photocatalytic procedures represents a very difficult task, mainly in view of the difficult separation of nanometric photocatalysts at the end of the process. ${ }^{8,9}$ To overcome these difficulties, many immobilized photocatalysts have been proposed, involving the use of glass-rings (Raschig rings) ${ }^{10}$ and glass-tubes, ${ }^{11}$ activated charcoal, ${ }^{8}$ silica, ${ }^{12}$ among other support materials. In some situations, the use of immobilized photocatalysts reduces the efficiency of the degradation process, in view of the considerable reduction of disposable sites for adsorption and catalysis..$^{13}$ In other conditions, the use of immobilized photocatalysts enhances the efficiency of the degradation process, mainly on account of the preliminary adsorption of the substrates onto the support surface. A fact that facilitates its approximation to the disposable catalytic sites. $^{14}$

Several works have shown a superior degradation efficiency of photocatalytic systems mediated by $\mathrm{ZnO} .{ }^{15,16}$ However, a small number of works related the use of immobilized forms of this photocatalyst, outstanding the good results observed by the use of $\mathrm{ZnO}$ immobilized in glass-rings ${ }^{10}$ and plates. ${ }^{17} \mathrm{As}$ far as, it is known only one work that relates the use of $\mathrm{ZnO}$ immobilized into calcium alginate beads, with excellent degradation capacity of textile dyes in reaction times of about $120 \mathrm{~min}^{18}$

In this work, the potentiality of immobilized forms of $\mathrm{TiO}_{2}$ and $\mathrm{ZnO}$ was evaluated, toward the photocatalytic degradation of camphor in aqueous solution. Camphor was selected as a model substrate due to its close chemical similarity with 2-methylisoborneol (2-MIB). 2-MIB is one of the chemicals with major influence on the quality of drinking water, on account of its, very low odor detection threshold. ${ }^{19}$ The photocatalytic degradation of 2-MIB by using $\mathrm{TiO}_{2}$ supported on Y-zeolites was recently reported, with results that demonstrate the best degradation capacity of the immobilized photocatalyst, mainly in consequence of the preliminary adsorption of 2-MIB into the support material. ${ }^{20}$

\section{Experimental}

\section{Chemical and reagents}

Camphor (Viafarma, 98\%) was used in aqueous solutions of $50 \mathrm{mg} \mathrm{L}^{-1}$. In heterogeneous photocatalytic processes, it was used titanium dioxide Degussa P-25 (75\% anatase $/ 25 \%$ rutile, BET $50 \mathrm{~m}^{2} \mathrm{~g}^{-1}$ ) and zinc oxide Merck (wurtzite, BET $4 \mathrm{~m}^{2} \mathrm{~g}^{-1}$ ). Immobilization studies involved the use of sodium alginate (Vetec, PA) and titanium (IV) butoxide (DuPont, 99\%). In liquid-liquid extraction procedures, it was used dichloromethane (Vetec, PA). Other reagents were of analytical grade.

Immobilization of $\mathrm{TiO}_{2}$ and $\mathrm{ZnO}$ in calcium alginate

The immobilizations of both photocatalysts were carried out according to procedures described by Rodríguez-Couto et al. ${ }^{18}$ A sodium alginate $(3 \% \mathrm{~m} / \mathrm{v})$ solution was initially prepared in deionized water. Afterward, a suspension was prepared by using $1 \mathrm{~L}$ of sodium alginate and $1 \mathrm{~g}$ of photocatalyst $\left(\mathrm{TiO}_{2}\right.$ or $\left.\mathrm{ZnO}\right)$. After thoroughly mixing, the calcium alginate beads were prepared by dropping the former suspension in an aqueous solution of calcium chloride $(2 \%, \mathrm{~m} / \mathrm{m})$ with the aid of a peristaltic pump.

\section{Immobilization of $\mathrm{TiO}_{2}$ in borosilicate Raschig rings}

The impregnation of $\mathrm{TiO}_{2}$ in borosilicate Raschig rings was carried out according to procedures described by Yeber et al. ${ }^{21}$ Glass rings $(5 \times 2 \mathrm{~mm})$ were left in contact for $45 \mathrm{~min}$ with a $5 \%(\mathrm{~m} / \mathrm{v})$ solution of titanium butoxide in ethanol. Afterward, the rings were calcinated at $450{ }^{\circ} \mathrm{C}$ for $45 \mathrm{~min}$. The process was repeated by four times.

\section{Characterization of the immobilized photocatalysts}

The surface morphologies of the supported catalysts were evaluated by using scanning electron microscopy (SEM) in combination with energy dispersive X-ray analysis on a JEOL microscope operating at $20 \mathrm{keV}$. The $\mathrm{X}$-ray powder diffraction (XRD) patterns were recorded on a Shimadzu XRD-6000 diffractometer using $\mathrm{Cu} \mathrm{K}_{\alpha}$ radiation $(\lambda=1.54 \AA$ ) operating at $40 \mathrm{kV}, 20 \mathrm{~mA}$ and scanning rate of 2 degree $\mathrm{min}^{-1}$. X-ray fluorescence 
analyses (EDXRF) were carried on a Shimadzu-EDX 700 spectrometer. Raman spectra were obtained in a Renishaw Raman Image spectrophotometer coupled to an optical microscope that focuses the incident radiation down to a $1 \mathrm{~mm}$ spot. An Ar laser (514 nm) with an incident potency of 50\% was used over the $200-1000 \mathrm{~cm}^{-1}$ region. UV-Vis spectra were recorded in a Shimadzu UV-2401 PC equipment, using $1 \mathrm{~cm}$ quartz cells.

\section{Photocatalytic treatment}

Photocatalytical experiments were carried out in a jacketed borosilicon-glass vessel $(250 \mathrm{~mL})$, equipped with magnetic stirrer, water refrigeration (operating temperature of $25 \pm 2{ }^{\circ} \mathrm{C}$ ) and oxygenation system (oxygen flow of $\left.45 \mathrm{~mL} \mathrm{~min}^{-1}\right)$. The UV radiation was provided by a medium-pressure mercury vapor lamp $(125 \mathrm{~W}$, maximal emission wavelength centered at $254 \mathrm{~nm}$ ), without the original glass-bulb, immersed in the samples by means of a quartz jacket. Under these conditions, the measured UV photon flux was $9.7 \times 10^{-5}$ Einstein s$^{-1}$ (uranyl-oxalate actinometry).

Samples of $250 \mathrm{~mL}$ were placed in the reactor and irradiated for different times, using a photocatalyst mass and a working $\mathrm{pH}$ previously optimized by factorial design. The $\mathrm{pH}$ value of the samples was adjusted with aqueous solutions of $\mathrm{HNO}_{3}$ and $\mathrm{NaOH}$. Samples were collected at regular intervals and submitted to analytical control.

To investigate the single effect of the adsorption on the photocatalyst surface, the degradation by photolysis and the removal by volatilization, experiments were carried out with suspensions of $\mathrm{TiO}_{2}$ (or $\mathrm{ZnO}$ ) in the dark, with single incidence of UV radiation and with single oxygenation (oxygen flow of $45 \mathrm{~mL} \mathrm{~min}^{-1}$ ), respectively.

All experiments were carried out in triplicate, observing a mean relative standard deviation of approximately $3 \%$.

\section{Analytical control}

The camphor degradation was monitored by gas chromatography with flame ionization detection (GC-FID) after extraction in dichloromethane. The chromatographic analysis was carried out in a Shimadzu 14B gas chromatographer, equipped with FID and a Shimadzu C-RGA area integrator. A $30 \mathrm{~m} \times 0.25 \mathrm{~mm}$ I.D., $0.25 \mu \mathrm{m}$ film thickness DB-Wax (J \& W Scientific) capillary column was used. Peak-area ratios between camphor and the internal standard ( $n$-octanol) were used to construct a calibration curve over the range of 5-50 $\mathrm{mg} \mathrm{L}^{-1}$. The typical variance coefficient was $2.5 \%$.
The total organic carbon (TOC) content was determined in a Shimadzu VCPH TOC analyzer. The calibration curve was made from a standard aqueous solution of potassium hydrogen phthalate over the range 5-200 $\mathrm{mg} \mathrm{L}^{-1}$. The typical variance coefficient was $2.0 \%$.

\section{Result and Discussions}

\section{Preliminary studies}

Initially, the effect of relevant operational variables $(\mathrm{pH}$ and photocatalyst concentration) in the degradation capacity of the photocatalytic process was evaluated by a $2^{2}$ factorial design, using suspended $\mathrm{TiO}_{2}$. For a better visualization, the results are shown as geometric representations in Figure 1, using the degradation of camphor at a reaction time of $60 \mathrm{~min}$ as analytical response. In both designs, a central point was assayed in triplicate, showing a mean standard deviation (SD) of $2 \%$.

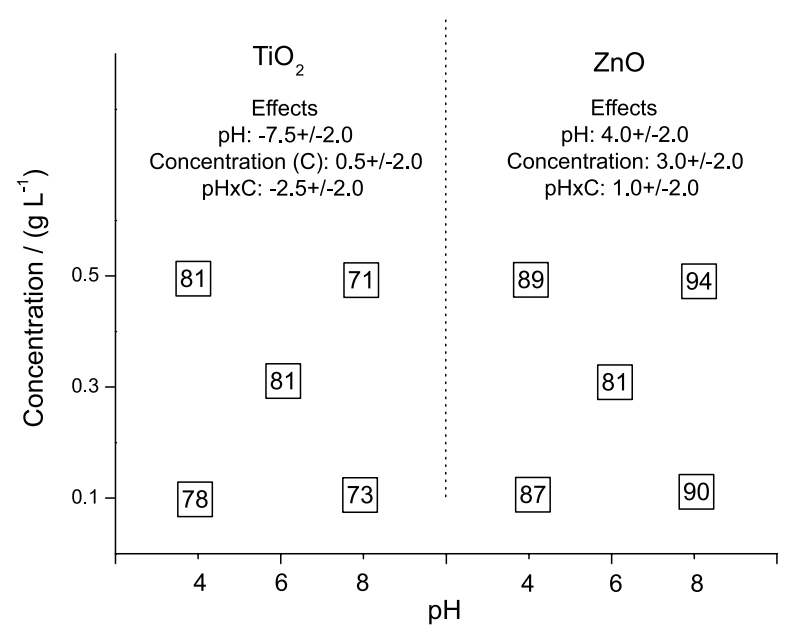

Figure 1. Geometric representation of the $2^{2}$ factorial design used to evaluate the effect of $\mathrm{pH}$ and photocatalyst concentration on the degradation of camphor by suspended $\mathrm{TiO}_{2}$ (camphor: $50 \mathrm{mg} \mathrm{L}^{-1}$, reaction time: $15 \mathrm{~min}$, monitoring: gas chromatography).

For $\mathrm{TiO}_{2}$ (Figure 1), changes on the photocatalyst concentration ( 0.1 to $\left.0.5 \mathrm{~g} \mathrm{~L}^{-1}\right)$ do not induce significant modification on the degradation capacity of the system, a fact that can be corroborated by a main effect $(0.5 \%)$ lower than the $\mathrm{SD}$ value $(2 \%)$. On the other hand, $\mathrm{pH}$ shows a negative main effect $(-7.5 \%)$, which implies a higher degradation capacity in $\mathrm{pH}$ values near to the inferior level (4.0). The interpretation of the $\mathrm{pH}$ effect is always a difficult task mainly due to its significant influence on the chemical structure of the substrate and in the superficial properties of the photocatalyst. $\mathrm{TiO}_{2}$ shows a zero-charge point at $\mathrm{pH} 6$, a fact that implies a positively charged surface at $\mathrm{pH}$ lower than 6 . Under these conditions, the migration 
of photo-generated electrons is favored, a fact that reduces the electron-hole combination and consequently improves the efficiency of the photochemical process. ${ }^{22}$

In studies involving the use of $\mathrm{ZnO}$ (Figure 1), effects of relevance were not observed. However, a slightly improved degradation capacity was observed at $\mathrm{pH} 8$, provably on account of the negative effect provoked by the dissolution of $\mathrm{ZnO}$ in acidic media.

In view of the preceding observations, the concentration of photocatalysts were fixed in $0.2 \mathrm{~g} \mathrm{~L}^{-1}$ and $\mathrm{pH}$ in 5.2, value that represents the natural $\mathrm{pH}$ of camphor aqueous solutions.

Because of the peculiar nature of the photocatalytic processes, the removal of camphor can be a result of some simultaneous processes, highlighting the adsorption on the photocatalyst surface, the losses by volatilization and the decomposition by photolytic degradation. In consequence, the single contribution of these processes was investigated, observing the results shown in Figure 2. Firstly, it is important to remark that, even when the preliminary adsorption of the substrates corresponds to an important condition for its photocatalytic degradation, the adsorption removal of camphor was not significant $(<10 \%)$, manly taking into account the removal by photocatalysis $(>90 \%)$. Furthermore, it is possible to observe a higher adsorption capacity of $\mathrm{TiO}_{2}$ probably due to its higher superficial area.

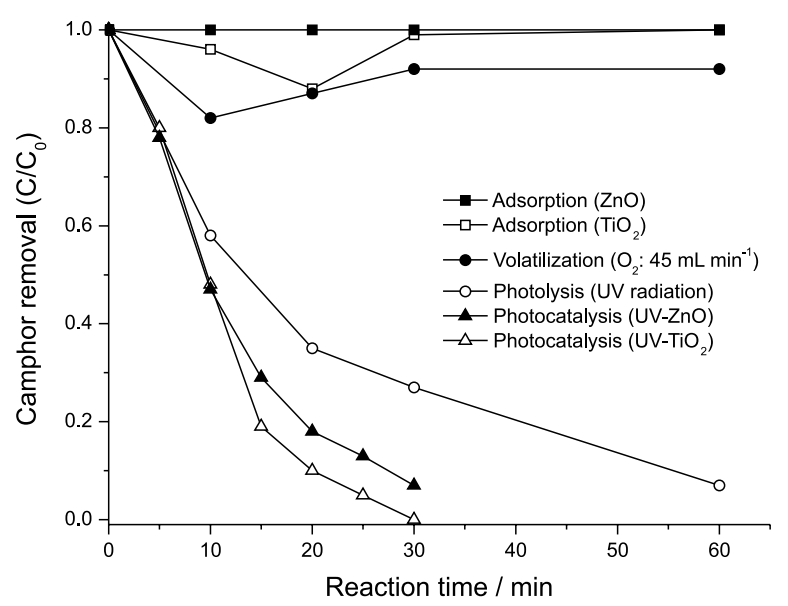

Figure 2. Removal of camphor by adsorption $\left(\mathrm{TiO}_{2}\right.$ or $\mathrm{ZnO}$ suspensions in the dark), volatilization by oxygenation $\left(\mathrm{O}_{2}: 45 \mathrm{~mL} \mathrm{~min}^{-1}\right)$, UV photolysis (single incidence of $\mathrm{UV}$ radiation) and heterogeneous photocatalysis $\left(\mathrm{TiO}_{2}\right.$ or $\mathrm{ZnO}$ suspensions under irradiation). Camphor: $50 \mathrm{mg} \mathrm{L}^{-1}, \mathrm{pH}$ : 5.2 , photocatalyst: $0.2 \mathrm{~g} \mathrm{~L}^{-1}$, monitoring: gas chromatography.

Under the experimental conditions of this study (oxygen flow of $45 \mathrm{~mL} \mathrm{~min}^{-1}$ ), the removal of camphor by volatilization was lower that $20 \%$.

The effect of the single photolysis needs to be emphasized, by reason of degradation ratios of about $70 \%$ at reaction times of $30 \mathrm{~min}$. Usually, the photolytic process involves the scission of more labile bonds, without expressive mineralization. ${ }^{23}$ In this study, the photolysis induced total organic carbon (TOC) removal lower than $20 \%$. While in photocatalytic processes, the TOC removal was higher than $50 \%(\mathrm{ZnO})$ and $85 \%\left(\mathrm{TiO}_{2}\right)$, at reaction times of $60 \mathrm{~min}$.

The photocatalysis mediated by both semiconductors permits fast camphor degradation with practically complete removal at reaction times of $30\left(\mathrm{TiO}_{2}\right)$ and $45 \mathrm{~min}(\mathrm{ZnO})$.

Immobilization of $\mathrm{TiO}_{2}$ and $\mathrm{ZnO}$ in calcium alginate

Alginate is a water soluble linear polysaccharide extracted from brown seaweed, containing alternating blocks of 1-4-linked $\alpha$-L-guluronic and $\beta$-D-mannuronic acid residues. The most important property of alginates is their ability to form gels by reaction with divalent cations such as $\mathrm{Ca}^{2+} .^{24}$ The gelation and cross-linking of the polymers lead to formation of a characteristic egg-box structure, which permits the encapsulation of many chemical species. ${ }^{25}$

In this work, $\mathrm{ZnO}$ and $\mathrm{TiO}_{2}$ were incorporated into the calcium alginate beads by mean of a very simple procedure, which permits the formation of regular spheres with average diameter of 2-3 mm. Characterization studies carried out by scanning electronic microscopy permitted the observation of a very irregular surface with diverse pore dimensions. The chemical mapping evidenced a homogeneous distribution of both photocatalyst into the bead surface (Figure 3).

The concentration of the photocatalysts in the alginate beads were determined by X-ray fluorescence spectrometry with results of about $0.4 \%(\mathrm{~m} / \mathrm{m})$ for both semiconductors. Characterization studies carried out by Raman spectroscopy do not reveal significant details mainly due to the severe interference from the support fluorescence.

The characterization by X-ray diffractometry (XRD) evidenced the amorphous nature of the calcium alginate, feature that makes difficulty the identification of the crystalline phases of $\mathrm{TiO}_{2}$. Anatase and rutile phases were observed in the step diffractogram acquired under reduced scanning velocity. In the characterization of alginate/ $\mathrm{ZnO}$, only one crystalline form of $\mathrm{ZnO}$ was evident. Moreover, it can be observed that, as presupposed, the phases of both oxides were not modified during the sample preparation, mainly in view of the mild used drying process (Figure 4).

Immobilization of $\mathrm{TiO}_{2}$ in glass rings

Many works report the efficient immobilization of $\mathrm{TiO}_{2}$ in glass supports, mainly by sol-gel processes involving the use of alcoxide precursors. ${ }^{26}$ 
a
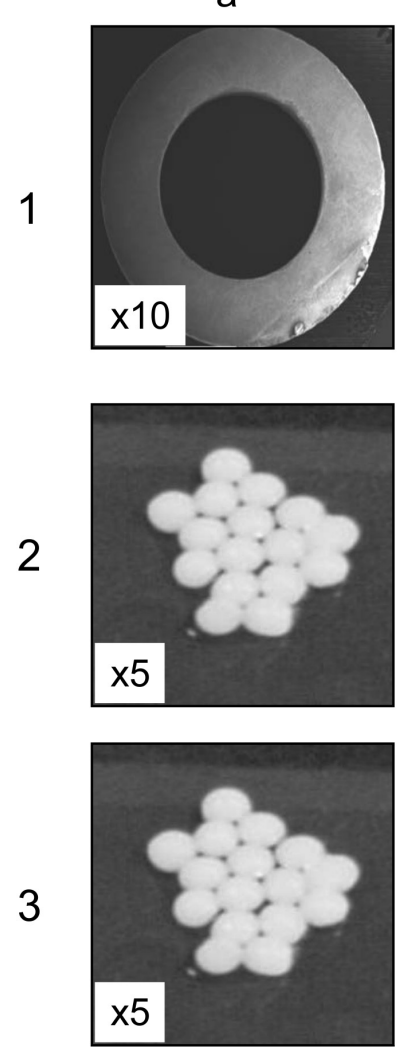

b


C
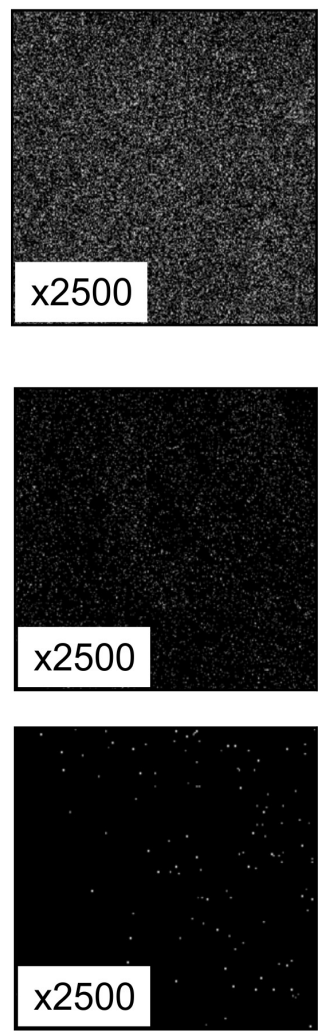

Figure 3. Electronic micrographs ( $\mathrm{a}$ and b) and chemical mapping (c) of $\mathrm{TiO}_{2} /$ borosilicate reaching rings (1), TiO $/ 2$ Alginate (2) and $\mathrm{ZnO} / \mathrm{Alginate}(3)$.


Figure 4. XRD patterns of calcium alginate and supported photocatalysts.

In this work, the XRD characterization did not revealed any crystalline phase of $\mathrm{TiO}_{2}$, but only the presence of an amorphous solid (borosilicate glass), while the X-ray fluorescence analysis showed a $\mathrm{TiO}_{2}$ concentration of about $15 \%(\mathrm{~m} / \mathrm{m})$. The UV spectra (Figure 5) showed a high similarity between the commercial Degussa $\mathrm{P} 25 \mathrm{TiO}_{2}$ and the supported form, with a slight absorption edge shifts toward higher wavelengths, probably

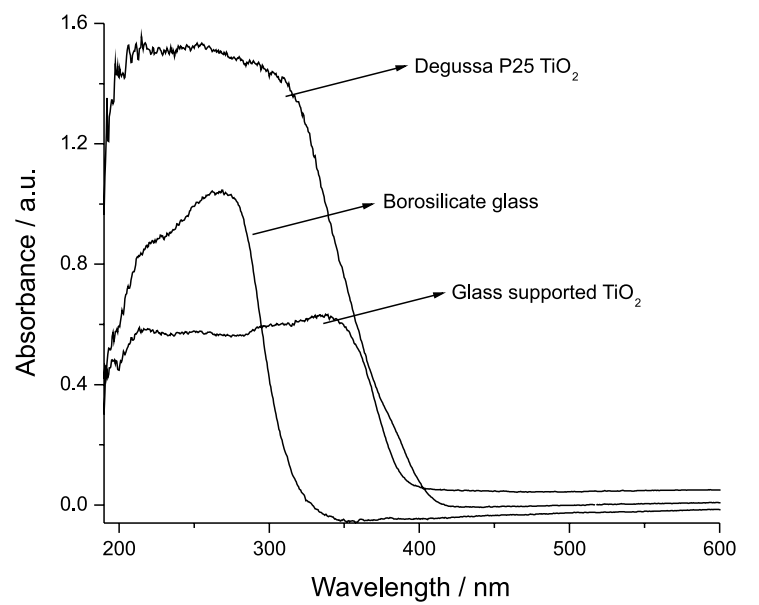

Figure 5. Electronic spectra of borosilicate glass, Degussa $\mathrm{P} 25 \mathrm{TiO}_{2}$ and $\mathrm{TiO}_{2}$ immobilized in borosilicate reaching rings.

on account of interactions between $\mathrm{TiO}_{2}$ and the glass support. $^{27}$

Raman spectroscopy analysis (Figure 6) reveals the presence of bands in 396,514 and $636 \mathrm{~cm}^{-1}$, attributed to the $\mathrm{B}_{1 \mathrm{~g}}, \mathrm{~A}_{1 \mathrm{~g}}+\mathrm{B}_{1 \mathrm{~g}}$ and $\mathrm{E}_{\mathrm{g}}$ anatase active modes. ${ }^{28}$

Characterization studies carried out by scanning electronic microscopy and chemical mapping evidenced a homogeneous distribution of $\mathrm{TiO}_{2}$ into the ring surface (Figure 3). 




Figura 6. Raman spectra of borosilicate glass, Degussa $\mathrm{P} 25 \mathrm{TiO}_{2}$ and $\mathrm{TiO}_{2}$ immobilized in borosilicate reaching rings.

Degradation studies with suspended and supported photocatalysts

After characterization, the efficiency of the immobilized material was evaluated toward the degradation of camphor aqueous solutions, with the same experimental conditions used in degradation studies involving suspended photocatalysts ( $\mathrm{pH}$ of camphor solution ca. 5.2 and $0.2 \mathrm{~g} \mathrm{~L}^{-1}$ of semiconductor mass).

In order to quantitatively compare the processes, kinetic parameters were calculated from the degradation profiles shown in Figure 7.

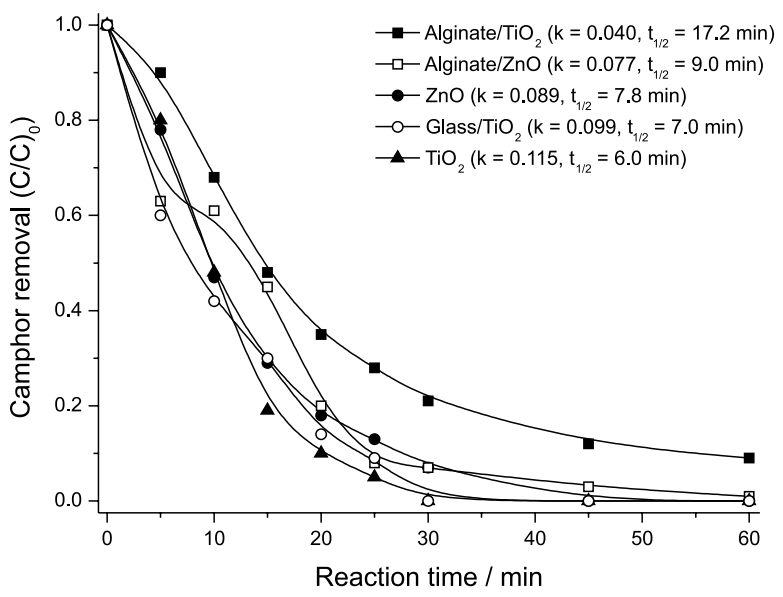

Figura 7. Degradation of camphor by photocatalysis using free and immobilized photocatalysts (camphor: $50 \mathrm{mg} \mathrm{L}^{-1}, \mathrm{pH}: 5.2$, photocatalyst: $0.2 \mathrm{~g} \mathrm{~L}^{-1}$, monitoring: gas chromatography).

Because of its heterogeneous character, the kinetics of the photocatalytic processes generally follows a LangmuirHinshelwood mechanism, defined as:

$\mathrm{r}=\mathrm{k} \theta=\mathrm{k}(\mathrm{KC} /(1+\mathrm{KC}))$ where $\mathrm{k}$ is the true rate constant, $\mathrm{K}$ is the constant of adsorption at equilibrium and $\mathrm{C}$ is the instantaneous concentration.

For diluted solutions, KC becomes $\quad<<1$. For this reason, the photocatalytic degradation of many organics substrates obeys apparently pseudo-first order kinetics at low initial substrate concentrations.

In this work, the quasi-exponential decay observed during the photocatalytic degradation of camphor, the linear relation observed between $\ln (\mathrm{C} / \mathrm{Co})$ and the reaction time indicate that, in our experimental conditions, the camphor degradation follows a pseudo-first order kinetic, as admitted in several works of similar nature. ${ }^{29}$

For $\mathrm{ZnO}$ (Figure 7), very similar results were observed in supported $\left(\mathrm{k}=0.077, \mathrm{t}_{1 / 2}=9.0 \mathrm{~min}\right)$ and unsupported $\left(\mathrm{k}=0.089, \mathrm{t}_{1 / 2}=7.5 \mathrm{~min}\right)$ systems, a fact that implies almost total removal of camphor in reaction times of about $60 \mathrm{~min}$. During the photocatalytic treatment, a slight decomposition of the alginate matrix was observed, a fact that provokes an also slight increase on the soluble TOC content. For this reason, it was not possible to assess de camphor mineralization.

The use of $\mathrm{TiO}_{2}$ immobilized in borosilicate rings allowed degradation rates that are fairly similar to those observed with the use of suspensions of $\mathrm{TiO}_{2}$ (Figure 7). That is, nearly complete degradation in reaction times of about $45 \mathrm{~min}$. However, the mineralization was significantly different. The use of suspensions of $\mathrm{TiO}_{2}$ allowed reduction of about $80 \%$ in the TOC content in reaction times of $60 \mathrm{~min}$, whereas immobilized system induced mineralization not superior to $50 \%$.

On the other hand, the degradation capacity of $\mathrm{TiO}_{2}$ immobilized in alginate $\left(\mathrm{k}=0.040, \mathrm{t}_{1 / 2}=17.2 \mathrm{~min}\right)$ was significantly lower than that observed with the use of $\mathrm{TiO}_{2}$ suspensions $\left(\mathrm{k}=0.115, \mathrm{t}_{1 / 2}=6.0 \mathrm{~min}\right)$ probably due to the significant area reduction observed in immobilized systems.

Unfortunately, few works have reported the photocataytic degradation of 2-MIB. In general, the results reported here are comparable with that related in the current literature for photocatalytic degradation of 2-MIB by suspensions of $\mathrm{TiO}_{2} \cdot{ }^{19}$ On the other hand, the use of $\mathrm{TiO}_{2}$ immobilized in glass-rings shows a better degradation performance than other immobilized forms, such as $\mathrm{TiO}_{2} /$ zeolites. ${ }^{20}$

\section{Conclusions}

First of all, it is important to remark that high degradation efficiency was observed in photocatalytic processes assisted by free $\mathrm{ZnO}$, in general with results that are comparable with those provided by $\mathrm{TiO}_{2}$. 
The degradation efficiency of $\mathrm{TiO}_{2}$ supported in reaching glass ring was also comparable with the performance of free conventional Degussa $\mathrm{P} 25 \mathrm{TiO}_{2}$. In both cases, almost total camphor removal was observed at reaction time lower than $60 \mathrm{~min}$.

The use of calcium alginate beads as immobilization matrix show some inconveniences, mainly represented by low degradation efficiency when compared with free photocatalysts and instability under photochemical reactions, a fact that induced losses of soluble total organic carbon.

\section{References}

1. Fujishima,A.; Rao, T. N.; Tryk, D. A.; J. Photochem. Photobiol., C 2000, 1,1 .

2. Fujishima, A.; Zhang, X.; Tryk, D. A.; Int. J. Hydrogen Energy 2007, 32, 2664.

3. Malato, S.; Fernández-Ibáñez, P.; Maldonado, M. I.; Blanco, J.; Gernjak, W.; Catal. Today 2009, 147, 1.

4. Devipriya S.; Yesodharan, S.; Sol Energy Mater. Sol. Cells 2005, $86,309$.

5. Woo, O. T.; Chung, W. K.; Wong, K. H.; Chow, A. T.; Wong, P. K.; J. Hazard Mater. 2009, 168, 1192.

6. Zayani, G.; Bousselmi, L.; Mhenni, F.; Ghrabi, A.; Desalination 2009, 246, 344.

7. Hsu, Y.-Y.; Hsiung, T.-L.; Wang, H.P.; Fukushima, Y.; Wei, Y.-L.; Chang, J.-E.; Mar. Pollut. Bull. 2008, 57, 873.

8. Wang, X.; Liu, Y.; Hu, Z.; Chen, Y.; Liu, W.; Zhao, G.; J. Hazard Mater. 2009, 169, 1061.

9. Khataee, A. R.; Pons, M. N.; Zahraa, O.; J. Hazard Mater. 2009, 168,451

10. Yeber, M. C.; Rodríguez, J.; Freer, J.; Durán, N.; Mansilla, H. D.; Chemosphere 2000, 41, 1193.

11. Lee, J.-C.; Kim, M-S.; Kim, B.-W.; Water Res. 2002, 36, 1776.

12. Pucher, P.; Benmami, M.; Azouani, R.; Krammer, G.; Chhor, K.; Bocquet, J.-F.; Kanaev, A. V.; Appl. Catal., A 2007, 332, 297.
13. Mascolo, G.; Comparelli, R.; Curri, M. L.; Lovecchio, G.; Lopez, A.; Agostiano, A.; J. Hazard Mater. 2007, 142, 130.

14. Gao Y.; Liu, H.; Mater. Chem. Phys. 2005, 92, 604.

15. Palominos, R. A.; Mondaca, M. A.; Giraldo, A.; Peñuela, G.; Pérez-Moya, M.; Mansilla, H. D.; Catal. Today 2009, 144, 100.

16. Sakthivel, S.; Neppolian, B.; Shankar, M. V.; Arabindoo, B.; Palanichamy, M.; Murugesan, V.; Sol. Energy Mater. Sol. Cells 2003, 77, 65 .

17. Behnajady, M. A.; Modirshahla, N.; Daneshvar, N.; Rabbani, M.; J. Hazard Mater. 2007, 140, 257.

18. Rodríguez-Couto, S.; Domínguez, A.; Sanromán, A.; Chemosphere 2002, 46, 83.

19. Lawton, L. A.; Robertson, P. K. J.; Robertson, R. F.; Bruce, F. G.; Appl. Catal., B 2003, 44, 9.

20. Yoon, S.-J.; Lee, Y. H.; Cho, W.-J.; Koh, I.-O.; Yoon, M.; Catal. Commun. 2007, 8, 1851.

21. Yeber, M. C.; Freer, J.; Baeza, J.; Mansilla, H. D. in Proceedings of the Second International Conference on Advanced Wastewater Treatment Recycling and Reuse, Milan, Italy, 1998, p. 907.

22. Zhao, S.; Xu, J.; Zhong, X. B.; Catal. Today 2004, 93-95, 857.

23. Abellán, M. N.; Giménez, J.; Esplugas, S.; Catal. Today 2009 , 144, 131.

24. Kumar, S.; Dwevedi, A.; Kayastha, A. M.; J. Mol. Catal. B: Enzym. 2009, 58, 138.

25. Bajpai S. K.; Sharma, S.; React. Funct. Polym. 2004, 59, 129.

26. Gelover, S.; Mondragón, P.; Jiménez, A.; J. Photochem. Photobiol, A 2004, 165, 241.

27. Gao X.; Wachs, I. E.; Catal. Today 1999, 51, 233.

28. Choi, H. C.; Jung, Y. M.; Kim, S. B.; Vib. Spectrosc. 2005, 37 , 33.

29. Martínez, C.; Canle, M.; Fernández, M. I.; Santaballa, J. A.; Faria, J.; Appl. Catal., B 2011, 102, 563.

Submitted: December 23, 2011 Published online: August 7, 2012 